\title{
Steering Institutionalization Through Institutional Work: The Case of an eProcurement System in Indonesian Local Government
}

\author{
Fathul Wahid \\ Department of Information Systems, \\ University of Agder, Kristiansand, Norway and \\ Department of Informatics, \\ Universitas Islam Indonesia, Yogyakarta, Indonesia \\ fathul.wahid@uia.no
}

\author{
Maung K. Sein \\ Department of Information Systems, \\ University of Agder, Kristiansand, Norway and \\ Luleå University of Technology, \\ Luleå, Sweden \\ maung.k.sein@uia.no
}

\begin{abstract}
Corruption is arguably one of the main hindrances to development. In their effort to combat corruption, governments in developing countries turn to information technology to enhance transparency in decision making. However, implementation of an information system in this context is not straightforward. Premised upon institutional theory, this interpretive case study traces the role of institutional actors in the institutionalization of an eProcurement system in Indonesian local government. It draws on different streams of research on institutional work to develop an interpretive lens to understand what institutional actors do to steer the institutionalization process. It identifies a set of institutional work carried out by them in disrupting the old institution, and, creating and maintaining the new one. The findings give a better understanding of the institutionalization process. It provides a fine-grained conceptualization of forms of institutional work, and its constituent dimensions.

Keywords: Institutional work, institutional theory, institutionalization, eProcurement, eGovernment, Indonesia, developing countries.
\end{abstract}

\section{Introduction}

Implementing eGovernment initiatives in developing countries is seldom straightforward due to various obstacles that have to be overcome $[1,2]$. However, some initiatives have been successfully institutionalized, while others have not. Although, in general, the eProcurement initiative in the Indonesian public sector could be considered as an example of the former [3], not all implementations at the local government level have successfully achieved their potential for curbing corrupt practices in public procurement. Despite this, some local governments have enjoyed considerable benefits from the successful institutionalization of the initiative.

In view of the low success rate of eGovernment implementation in developing countries [e.g., 2], it is important to understand why some systems are successfully institutionalized. It is even more important in eProcurement since the main purpose is to curb corruption. This practice is endemic in many, if not most, developing countries and is believed to be one of the main hindrances of development [4]

The question then is what are the critical factors behind a successful implementation of eGovernment systems in general and eProcurement systems in particular. The literature points to the influential role played by institutional actors [5, 6]. However, only a few studies examine why they are vital in implementing an eGovernment initiative and how successful institutional entrepreneurs go about doing it Institutional entrepreneurs are purposeful actors who have resources at their disposal and social and political skills and social position to lead change [7]. They initiate divergent changes and actively participate in the implementation of these changes, to transform the existing institutions or to create new ones [8].

IS scholars have called for research to pay more attention to the role of individuals in the implementation of information systems [3,9] through a fine-grained analysis of the situated practices $[10,11]$. Others have called for research to study institutionalization using an historical approach by focusing on its process rather on its outcome (i.e., an institution) [12], specifically in the context of public sector [13].

In this paper, we aim at answering these challenges. Drawing upon institutional theory, we bring in the concept of institutional work introduced by Lawrence and Suddaby [14] to better understand what institutional entrepreneurs do during the institutionalization process. The research question we examined can be stated as: how do the institutional entrepreneurs carry out institutional work during the institutionalization process?

To answer this question, we conducted a case study 
in the Indonesian city of Yogyakarta that has successfully institutionalized the eProcurement initiative. Other aspects of the institutionalization process have been reported elsewhere. In this paper, we focus on the role of institutional entrepreneurs and the institutional work carried out by them. To frame our study, we specifically draw upon the conceptualization of institutional work by Lawrence and Suddaby [14], categorization of the institutional work proposed by Tracey et al. [15], and strategies in resource mobilization proposed by Dorado [16].

The rest of the paper is structured as follows. Section 2 lays the conceptual groundwork of our study by first briefly discussing procurement in the public sector and then elaborating on the concept of institutional work. Section 3 explains the research method, and Section 4 presents the findings. Section 5 discusses the findings, and Section 6 concludes the paper by listing the contributions of the paper, outlining the limitations of the study, and offering future research directions.

\section{Conceptual Premises}

\subsection{Procurement in the public sector}

eProcurement refers to "the use of integrated (commonly web-based) communication systems for the conduct of part or all of the purchasing process; a process that may incorporate stages from the initial need identification by users, through search, sourcing, negotiation, ordering, receipt and post-purchase review" [17]. In practice, some eProcurement systems provide information only (eAnnouncement), while others facilitate transaction [18]. The system we studied falls in the latter category.

The extant literature reports a number of benefits of eProcurement systems for the adopting organization. They include a more efficient procurement process, cost reduction, and improved internal service and status of the purchasing function [17-19]. Specifically in the public sector, such systems offer some additional benefits such as enhanced transparency, better access for non-local bidders, better access for small and medium-sized enterprises (SMEs), and corruption avoidance [18]. The last benefit is even more important in a highly corrupt context $[4,18]$.

In general, public eProcurement practice is more complicated than in the private sector [20]. It must adhere to a number of rigid regulations, it depends on a political decision, the variety of goods or services purchased is greater, the transparency becomes its basic requirement, and it usually involves a variety of stakeholders with different and often conflicting agendas. Systems are often implemented under a unified public procurement plan that involves different government agencies (such as different departments)
[19-21]. Consequently, institutionalization of such systems becomes challenging and institutional work needed to be done becomes more complex.

\subsection{Institutional Work}

Institutional work refers to "the sets of practices through which individual and collective actors create, maintain and disrupt the institutions of organizational fields" [14]. This notion helps us to understand how institutional entrepreneurs and institutions interact with each other, and how actors creatively navigate organizational changes.

Institutional work has been grouped into three categories based on the stage of institutionalization: institutional work for creating, maintaining and disrupting institutions [14]. Institutional work for creating institutions may manifest itself in various forms, such as advocating a practice to other actors through direct social suasion and grounding a practice in a broader normative framework. When a new institution is created, the old institution often starts to erode or deinstitutionalize at the same time [22]. Institutional work for maintaining include deterring by establishing coercive power to drive institutional change and creating rules that facilitate, supplement and support institutions. Lastly, to disrupt institutions, institutional entrepreneurs may disconnect sanctions from a set of practices and disassociate a practice from its moral foundations. Table 1 lists a number of specific institutional works carried out at different stages of institutionalization. The table is based on Lawrence and Suddaby [14].

Table 1. Institutional work at stages of institutionalization

\begin{tabular}{|l|l|}
\hline Stage & Examples \\
\hline Disrupting & Disconnecting sanctions \\
& Disassociating moral foundations \\
& Undermining assumptions and beliefs \\
\hline Creating & Advocacy \\
& Defining \\
& Vesting \\
& Constructing identities \\
& Changing normative associations \\
& Constructing normative networks \\
& Mimicry \\
& Theorizing \\
& Educating \\
\hline Maintaining & Enabling work \\
& Policing \\
& Deterring \\
& Valourizing and demonizing \\
& Mythologizing \\
& Embedding and routinizing \\
\hline
\end{tabular}

Source: [16]

The institutional work carried out by institutional entrepreneurs are of three types: political work, 
technical work and cultural work [23]. Political work involves the enactment of rules and regulations through exercise of coercive power [14]. This requires considerable political skill on the part of institutional entrepreneurs. Technical work involves the construction of 'mental models' and shared world views [24]. It may manifest itself in various forms, such as through embedding and routinizing by actively infusing the normative foundations of an institution into day-to-day routines; and by educating actors in the skills and knowledge needed to support the new institution [14]. Here, institutional actors need to have analytical skills. Cultural work refers to practices that stimulate common ways of acting and behaving [23]. Here, the institutional entrepreneurs need cultural skills, such as an ability to frame an institution in terms of broader values and to create common identities [23]. Table 2 summarizes these concepts. The table is based on Perkman and Spicer [23].

Table 2. Type of institutional work

\begin{tabular}{|l|l|}
\hline Type & Examples \\
\hline Cultural & Constructing normative networks \\
& Constructing identities \\
& Changing normative associations \\
\hline Political & Advocacy \\
& Defining \\
& Vesting \\
\hline Technical & Theorizing \\
& Standardizing \\
& Mimicry \\
& Educating \\
\hline
\end{tabular}

Source: [25]

\section{Context and Research Method}

\subsection{The context}

eProcurement was formally adopted by the Indonesian government in April 2007. One of the strategic objectives of this initiative is to improve the transparency and accountability of public procurement. This objective has gained ground in Indonesia because budget leakage in public procurement has reached an alarming level. Several sources indicate that between $10 \%$ and $50 \%$ of the public procurement budget has been misappropriated [e.g., 25, 26]. This is a huge number since public expenditures account for $30 \%$ to $40 \%$ of total national spending in Indonesia [18].

Corruption that affects public procurement in Indonesia involves a wide spectrum of individuals and organizations, including political leaders, judicial figures, senior administrators and officials in procurement roles, as well as suppliers and contractors [27]. Therefore, it is important to have sound processes and proper management to reduce and minimize the potential for irregularities and misconduct [18].

By the end of 2012, the eProcurement system had been used by 731 government agencies at the national and local levels across 33 provinces throughout Indonesia. Yogyakarta implemented eProcurement in 2008 and by the end of that year, 11 work packages had been successfully completed with the help of the eProcurement system. In 2009, all work packages with a value greater than IDR 500 million (51 work packages) had to be tendered via the eProcurement system. At the beginning of 2009, Yogyakarta was described by Transparency International Indonesia as the cleanest city in the country in terms of its anticorruption practices. Since 2010, the eProcurement system had been used for all tenders valued at more than IDR 100 million. By the end of 2012, the system had been used for 788 tenders.

\subsection{Research approach}

This study is interpretative in nature. Our involvement in the process was not participatory. Therefore, this study is best described as a case study that involves longitudinal analysis.

We collected data mainly through interviews. We interviewed a variety of key players in eProcurement or eGovernment implementa-tion at various levels. The interviewees were the mayor of the city of Yogyakarta, four heads/vice-heads of departments, three heads of divisions and three administrators. We used the snowball method to select the interviewees. Some of them were no longer involved, such as the former head of the IT division who was later assigned to different tasks not related to the eProcurement initiative. He was the first informant who pointed to other relevant informants. In addition, we consulted the existing organizational structure to identify potential informants. Our intention in involving key players at different levels as research informants was to enable us to make better sense of the phenomenon under investigation [28]. We also did this to avoid elite bias [29], i.e., overweighting data from articulate, wellinformed, usually high-status informants and, conversely, under-representing data from less articulate and lower-status ones.

We conducted eleven interviews which were between 30 and 150 minutes long, between July and August 2011. Most of the interviews were recorded. In order to ensure the validity of our interpretation of the phenomenon, whenever possible, we conducted member checks $[28,30]$, mostly through an informal discussion with three of the interviewees. In these discussions, we obtained additional information for some areas that were not obvious during the previous interviews. In addition to the interviews, to increase the validity, we also collected data from written documents/reports and other secondary data such as news presented in the media, field observations. In 
addition, one of the authors participated in a national meeting of eProcurement agencies.

In analysing the data, we used concepts from institutional work as templates in the coding process. We started with the list shown in Table 1 and Table 2, but soon realized that they did not capture all the types of institutional work revealed by the data. Subsequently, we added concepts from Tracey et al. [15] and Dorado [16]. The final list of concepts used in the data analysis is shown in Table 3. To theorize from the process data, we used the temporal bracketing sensemaking strategy proposed by Langley [31]. This strategy focuses on identifying phases of the process and can be applied to one detailed case. In doing so, we arranged the emerging concepts in a timeline to examine the possible shifts of each concept over time. Figure 1 illustrates the outcome of this temporal bracketing process.

\section{Research Findings}

Since our focus is on the trajectory of the institutionalization process, we arrange our findings according to its stages: disrupting an old institution, creating and maintaining a new one.

\subsection{Disrupting an old institution}

One of the challenges faced by the Indonesian government is eradicating highly institutionalized corrupt practices. To cope with this, a Presidential Instruction was enacted at the end of 2004. An explicitly stated strategy was using an eProcurement system in the public procurement process. Since then, several government agencies have tried to implement their own eProcurement systems, such as the cities of Surabaya and Bogor. No integration efforts across government agencies were made at that time.

In the middle of 2007, the mayor of Yogyakarta declared his intention to adopt the eProcurement system, although the supporting infrastructure was not yet in place. The mayor did not consider the existing rigid manual procedures for public procurement as sufficient. He saw a disconnection between the existing manual structure and the espoused moral foundation of being transparent and accountable (as stated explicitly in the Presidential). Here, the institutionalized current public procurement practice began to be disrupted or deinstitutionalized by disassociating it from its moral foundation. This is an example of cultural work which is vital where corruption was ingrained. For example, a survey of 792 vendors conducted by the Indonesia Procurement Watch indicated that $92 \%$ of them were involved at least once in a corrupt procurement process by bribing the procurement officers. Moreover, around $80 \%$ of the corruption cases reported to the Corruption Eradication Commission (Komisi Pemberantasan
Korupsi $[\mathrm{KPK}]$ ) had something to do with public procurement practice [32]. One of the causes was the possible direct personal communication between the vendors and the procurement officers. One eProcurement administrator asserted:

"[At that time], the direct communication between the internal procurement committee and vendors, and between vendors, would give an opportunity for 'affairs'."

To sum up, institutional work for disrupting the old procurement practice was disassociating it from its moral foundation and the type was primarily cultural.

\subsection{Creating a new institution}

At this stage, according to the mayor, instilling values was very important. Once the values were instilled, the rest of the initiatives would be easier to advance. He argued:

"At first, I only cultivated values and shaped them. The hardest part [in the institutional change] is if there are no values. ... An institution is like a box and its foundation is values".

An example of the values instilled was the idea that information technology should enable them to work more transparently and accountably. The mayor thus carried out an institutional work by changing the normative association of the public procurement practice. The eProcurement system was expected to support a more transparent and accountable public procurement practice. This is another illustration of cultural work.

By the middle of 2007, the idea of adopting the eProcurement system had already been declared, but how to implement the idea was still not clear. An internal team consisting of people from various departments was then appointed to conduct a preparation study. The team visited some government agencies that had been using an eProcurement system. At first, in order to speed up the implementation, the city of Yogyakarta decided to use the systems already implemented in the cities of Surabaya and Bogor. During this process, the team came to know that the National Development Planning Agency (Badan Perencanaan Pembangunan Nasional [Bappenas]) was in the process of initiating an integrated eProcurement system nationally. The first batch of pilot projects was carried out in five provinces which did not include Yogyakarta's province. After negotiation, Bappenas

\footnotetext{
${ }^{1}$ Here, 'affairs' is a euphemism for unethical or illegal deals between the procurement officer and the vendors or between the vendors. These 'affairs' created information asymmetry between the vendors; those with good information access to the procurement committee gained an advantage. They could also offer an opportunity for the vendors to make a deal to enable one of them to win the tender.
} 
agreed to include Yogyakarta in this first batch, provided the city used its own budget for the purpose.

The preliminary study conducted by the team recommended that Yogyakarta needed some more years to prepare before adopting the eProcurement system in 2010. The existing limitations (e.g. inadequate infrastructure) did not deter the mayor who insisted on starting to use the eProcurement in 2008 after several months of preparation. Here, the mayor came up with a counterfactual thinking - a set of cognitive processes that allows actors to envision unexpected or unusual approaches in order to solve a certain problem and is an illustration of cultural work. Some informants called this the mayor's commitment. A head of department asserted:

"If the mayor is committed, then the process can be accelerated. ... Based on information we got from other districts, many of them are willing to accelerate the adoption of the eProcurement, but their mayor or head of district gives no responses. There are also some opposite cases."

Towards the end of 2007, the mayor started to mobilize support to implement the system. The agreement with Bappenas was formalized in March 2008. Parts of the agreement stated that the city of Yogyakarta should allocate its own budget for implementing the system and during the first year (2008) they should use the system for at least nine tenders. At this point, the local eProcurement initiative was connected to the macro-level discourse, a national eProcurement initiative. We see another instance of political work.

Since the benefits of adopting the eProcurement system had not yet been demonstrated at that time, the mayor began to mobilize needed resources and allies to support the initiative. In addition, to cultivate awareness among the civil servants against the corrupt practices, the mayor invited the commissioner from KPK to give a series of talks. The talks were attended by civil servants, members of the local parliament, and representatives of vendors' associations. Eventually, all the civil servants signed an Integrity Pact to eschew corrupt practice. Here, the mayor tried to align the local eProcurement initiative with highly legitimate actors, in this case, the KPK. This is political work. At the same time, the mayor adopted a convening resource mobilization strategy (an illustration of cultural work). During the preparation, the mayor needed around IDR 900 million for infrastructure, facilities and training; but this was impossible without the approval of the local parliament. This necessitated yet another convening strategy and cultural work.

As part of the preparation, the mayor assigned a team of 10 people to attend intensive training at Bappenas in Jakarta. Tellingly, the team from
Yogyakarta was the first group to attend the training, even before the groups from the originally selected five provinces. A series of training sessions on using the system was also conducted by the eProcurement officers for the local vendors. Here, educating the eProcurement officers and the vendors was very important. In addition, internal recruitment of eProcurement committee members was regularly conducted. We see the first instance of technical institutional work here. Officially, the eProcurement system was launched on July 25, 2008.

To sum up, institutional work carried out by the institutional actors in creating a new institution (i.e., the new eProcurement practice) was changing normative association, counterfactual thinking, convening, connecting to the macro-level discourse, aligning with highly legitimate actors, and educating. The work was mainly cultural and to a lesser extent political in nature while technical work makes its first appearance.

\subsection{Maintaining the new institution}

The constraints (i.e., policy, regulations) made by Bappenas (and subsequently by LKPP) were used by the mayor to legitimize the initiative. In addition, the mayor carried out a policing institutional work. In July 2008, a Mayor's Decree was enacted upon to guide the eProcurement implementation. This decree was also used as a basis for establishing a local eProcurement agency (Layanan Pengadaan Secara Elektronik [LPSE]).

After the eProcurement system had been in place for one year, its benefits began to materialize. At the end of 2008, after the system had been used for 11 tenders, it had provided $4.54 \%$ efficiency. From this point, the mayor started to exercise his power by adopting leveraging resource mobilization strategy, a political work. Part of this was done by allocating a sufficient amount of the budget (around IDR 200 million/year) to maintain the infrastructure and to continue providing free training for new vendors.

Although the eProcurement practice was improved gradually, the mayor also carried out deterring institutional work by issuing more decrees to guide further adoption of the system, clearly a political work. Examples include Mayor's Decree concerning the guidelines on using the local government budget (Anggaran Pendapatan dan Belanja Daerah [APBD]) and Mayor's Decree concerning electronic procurement at the LPSE. The latter lowered the threshold for work packages tendered using the eProcurement system, from IDR 500 million in 2009 to IDR 100 million from 2010 onwards. This political work created coercive barriers for some departments that previously were reluctant to use the system. To 
consider this contextual factor, the mayor chose a gradual implementation strategy.

We identified another institutional work at this stage. The mayor decided on some enabling works and supported others which are of technical nature. At the end of 2009, he established the Procurement Service Unit (Unit Layanan Pengadaan [ULP]) to help the LPSE. Annually, the Section for Controlling of Development (Bagian Pengendalian Pembangunan [Bagian Dalbang]) selected around 50 procurement officers from 250 certified civil servants in public procurement. The selected officers were appointed to one year of service at the ULP. After using the eProcurement system, they received a better incentive, with bonuses ranging from IDR 150,000 to IDR 700,000 per tender. At this point, the new practices started to be typified, when specific actors become responsible for specified actions. Another enabling work carried out was continuously maintaining and upgrading of the system, partly to adopt newer versions released by the LKPP. In addition, to provide a better service to the vendors, the LPSE also provided a room with a reliable Internet connection that could be used by the vendors to access the eProcurement system when they had trouble with it. All these typify technical institutional work.

New routines emerged. The departments practised better procurement planning and the tender schedules were reviewed and announced quarterly. This provided the vendors with sufficient time to prepare a bid and avoided information asymmetry between the vendors. To create a better basis for planning in terms of determining itemized ceiling values for each work package, a regular survey was conducted. In addition to providing free training for new vendors, internal training about the eProcurement system and practice for all the departments were also held annually. To keep pace with changes at the national level, such as new regulations and policies made by the LKPP, close collaboration and communication were maintained illustrating political work. This was done, for instance, by regularly attending biannual national gatherings, reporting the problems through a trouble ticketing system, and accessing immediate advice for emergency cases. All these became embedded and routinized practices and exemplify technical institutional work.

To sum up, for maintaining the new institution, in addition to those presented in the previous section, the institutional actors also did the following institutional works: policing, leveraging, deterring, enabling work, and embedding and routinizing. We see a predominance of political and technical work here but could not detect any cultural work.

\subsection{Summary of the findings}

Table 3 summarizes the institutional work undertaken by the institutional actors during the institutionalization process of the eProcurement system. The table clearly defines institutional works and their association with the institutionalization stages, along with the type of work and our empirical findings. The association between institutional work and the stage of institutionalization was based on the work of Lawrence and Suddaby [14] and categorization of the institutional work type was guided by Tracey et al. [15]. The concept of resource mobilization proposed by Dorado [16] enriched the notion of institutional work. However, Table 3 should not be interpreted in a deterministic way. The findings are discussed in the following section.

Table 3. Institutional work during the institutionalization process

\begin{tabular}{|c|c|c|c|c|}
\hline $\begin{array}{l}\text { Institutionali- } \\
\text { zation stage }\end{array}$ & Institutional work* & Definition & Empirical evidence & \begin{tabular}{|c|} 
Type of \\
institutional \\
work
\end{tabular} \\
\hline Disrupting & $\begin{array}{l}\text { Disassociating } \\
\text { moral foundation }\end{array}$ & $\begin{array}{l}\text { Disassociating the practice from its } \\
\text { moral foundation as appropriate } \\
\text { with a specific cultural context }\end{array}$ & $\begin{array}{l}\text { The mayor considered that the old procurement } \\
\text { system was no longer sufficient to ensure } \\
\text { transparent and accountable procurement processes }\end{array}$ & Cultural \\
\hline \multirow[t]{5}{*}{ Creating } & $\begin{array}{l}\text { Changing } \\
\text { normative } \\
\text { associations }\end{array}$ & $\begin{array}{l}\text { Remaking the connections between } \\
\text { a set of practices and the moral } \\
\text { foundation for those practices }\end{array}$ & $\begin{array}{l}\text { The mayor instilled values that that information } \\
\text { technology should enable the government to work } \\
\text { more transparent and accountable }\end{array}$ & Cultural \\
\hline & $\begin{array}{l}\text { Counterfactual } \\
\text { thinking }\end{array}$ & $\begin{array}{l}\text { Introducing a new way of thinking } \\
\text { that is against the common or } \\
\text { conventional wisdom }\end{array}$ & $\begin{array}{l}\text { The mayor insisted to implement the new } \\
\text { eProcurement system although the results of the } \\
\text { preliminary study told that the city was not ready yet }\end{array}$ & Cultural \\
\hline & Convening & $\begin{array}{l}\text { Mobilizing allies and support by } \\
\text { using deliberate technique of social } \\
\text { suasion }\end{array}$ & $\begin{array}{l}\text { The mayor mobilized resources and support from } \\
\text { various stakeholders (such as head of department } \\
\text { and local parliament) }\end{array}$ & Cultural \\
\hline & $\begin{array}{l}\text { Connecting to the } \\
\text { macro-level } \\
\text { discourse }\end{array}$ & $\begin{array}{l}\text { Making connection of a set of } \\
\text { practices to relevant external } \\
\text { practices beyond their local } \\
\text { organizational boundary }\end{array}$ & $\begin{array}{l}\text { The mayor signed a memorandum of understanding } \\
\text { (MoU) with Bappenas to become a part of the pilot } \\
\text { projects to implement the new national } \\
\text { eProcurement system }\end{array}$ & Political \\
\hline & $\begin{array}{l}\text { Aligning with } \\
\text { highly legitimate } \\
\text { actors }\end{array}$ & $\begin{array}{l}\text { Building relationships with highly } \\
\text { legitimate actors that may provide } \\
\text { authorization }\end{array}$ & $\begin{array}{l}\text { The mayor invited KPK to give talk to raise } \\
\text { awareness of the civil servant to reject corrupt } \\
\text { practices }\end{array}$ & \begin{tabular}{|l|} 
Political \\
\end{tabular} \\
\hline
\end{tabular}


Table 3. (continued)

\begin{tabular}{|c|c|c|c|c|}
\hline $\begin{array}{l}\text { Institutionali- } \\
\text { zation stage }\end{array}$ & Institutional work* & Definition & Empirical evidence & $\begin{array}{c}\text { Type of } \\
\text { institutional } \\
\text { work }\end{array}$ \\
\hline \multirow[t]{5}{*}{ Maintaining } & Policing & $\begin{array}{l}\text { Enacting regulation through } \\
\text { coercive power exercise to enable } \\
\text { or support the new practices }\end{array}$ & $\begin{array}{l}\text { The mayor enacted a set of policies and local } \\
\text { regulations to guide the implementation of the new } \\
\text { system }\end{array}$ & Political \\
\hline & Leveraging & $\begin{array}{l}\text { Mobilizing allies and support by } \\
\text { using coercive political power }\end{array}$ & $\begin{array}{l}\text { The mayor mobilized resources, such as, by } \\
\text { allocating enough budget to support the further } \\
\text { implementation of the new system }\end{array}$ & Political \\
\hline & Deterring & $\begin{array}{l}\text { Establishing coercive barriers for } \\
\text { those who are reluctant to enrol in } \\
\text { the new practices }\end{array}$ & $\begin{array}{l}\text { The mayor enacted other local regulations to force } \\
\text { other stakeholders (i.e., head of departments) to } \\
\text { support the adoption of the new system }\end{array}$ & Political \\
\hline & Enabling work & $\begin{array}{l}\text { Creating roles and practices that } \\
\text { facilitate, supplement and support } \\
\text { institutions, such as creating new } \\
\text { agency or allocating resources }\end{array}$ & $\begin{array}{l}\text { The mayor established ULP, regularly made internal } \\
\text { recruitment for the eProcurement committee } \\
\text { members, and LPSE continuously maintained and } \\
\text { upgraded the new system }\end{array}$ & Technical \\
\hline & $\begin{array}{l}\text { Embedding and } \\
\text { routinizing }\end{array}$ & $\begin{array}{l}\text { Ensuring that the new practices } \\
\text { become routines and integrated } \\
\text { parts of the organizational practices }\end{array}$ & $\begin{array}{l}\text { LPSE regularly conducted a series of training for } \\
\text { vendors, maintained a close communication with } \\
\text { LKPP, and participated actively in national } \\
\text { gathering held by LKPP }\end{array}$ & Technical \\
\hline
\end{tabular}

Notes: *Categories of institutional work and their definitions were inspired by Lawrence and Suddaby [14], Tracey et al. [15] and Dorado [16]. However, the definitions were contextualized.

\section{Discussion}

Figure 1 depicts the timeline of institutional work carried out by the institutional entrepreneurs during the institutionalization process. We structure our discussion in this section around this figure. The actions of the dominant actor, the mayor are keyed in shaded circles while those of other actors are keyed in clear circles. In this figure, the association between the institutional work and the institutionalization stages (i.e., disrupting, creating and maintaining), should not be interpreted in a deterministic way. For example, educating institutional work (see points $\mathrm{G}, \mathrm{J}, \mathrm{L}, \mathrm{R}$, and $\mathrm{U}$ ), in addition to supporting creation of institutions also supports maintaining of the new institutions.

As we pointed out above, different types of institutional work dominated at different institutionalization stages. For example cultural work was dominant at the creation stage while political and technical works were more prominent in the later stages. Below, we discuss this general pattern.

Cultural institutional work is very important at the beginning of the institutionalization process, since in most cases the limited number of institutional actors (in this case, the mayor is the main actor) need to frame new practices in ways that appeal to a broader audience [33]. This kind of institutional work mainly aims to promote discourse that associates new practices with new norms or values [23]. This is in line with the instilling values perspective of the institutionalization process [24].

At this stage of disruption and at the early phase of creation of an institution, therefore, the dominant actors disconnect the old practice from its moral foundations (point A) and replace it with the new practice with a strong values-based justification (point
B) [cf. 6]. In our case, this was done by introducing the counterfactual thinking (point $\mathrm{C}$ ) that challenged the broadly accepted common wisdom [cf. 15]. It was not surprising then that at this point, some resistance from the affected actors emerged. To cope with this issue, therefore, the cultural skills of the actors are very important for creating collective awareness through, for example, a convening resource mobilization strategy (point D). This strategy is important for overcoming collective inaction [16].

As parts of institutional work in creating a new institution, the mayor also sent a small team of future eProcurement officers to attend a training held by LKPP (point G). This could not have been done without the collaboration of another actor, which in this case was Bagian Dalbang who executed its own resource mobilization strategy by recruiting new eProcurement members internally (point $\mathrm{H}$ ). The team then arranged a series of regular training for local vendors conducted by LPSE which was set up by the mayor as part of enabling institutional work (point I). These training sessions at the beginning might be considered as educating institutional work (point J), while at a later stage (points $\mathrm{L}, \mathrm{R}$ and $\mathrm{U}$ ), they could be regarded as parts of embedding and routinizing institutional work along with maintaining a close com munication with upper level agencies (i.e., LKPP points $\mathrm{Q}$ and $\mathrm{S}$ ). Internal recruitment of eProcurement committee members, especially that was carried out at the later stage (points $\mathrm{P}$ and $\mathrm{V}$ ) also belonged to this type of institutional work.

In order to mobilize more allies and support, political institutional work was then undertaken by the institutional actors. In this case, this was carried out at the later stages of creating and maintaining the new 


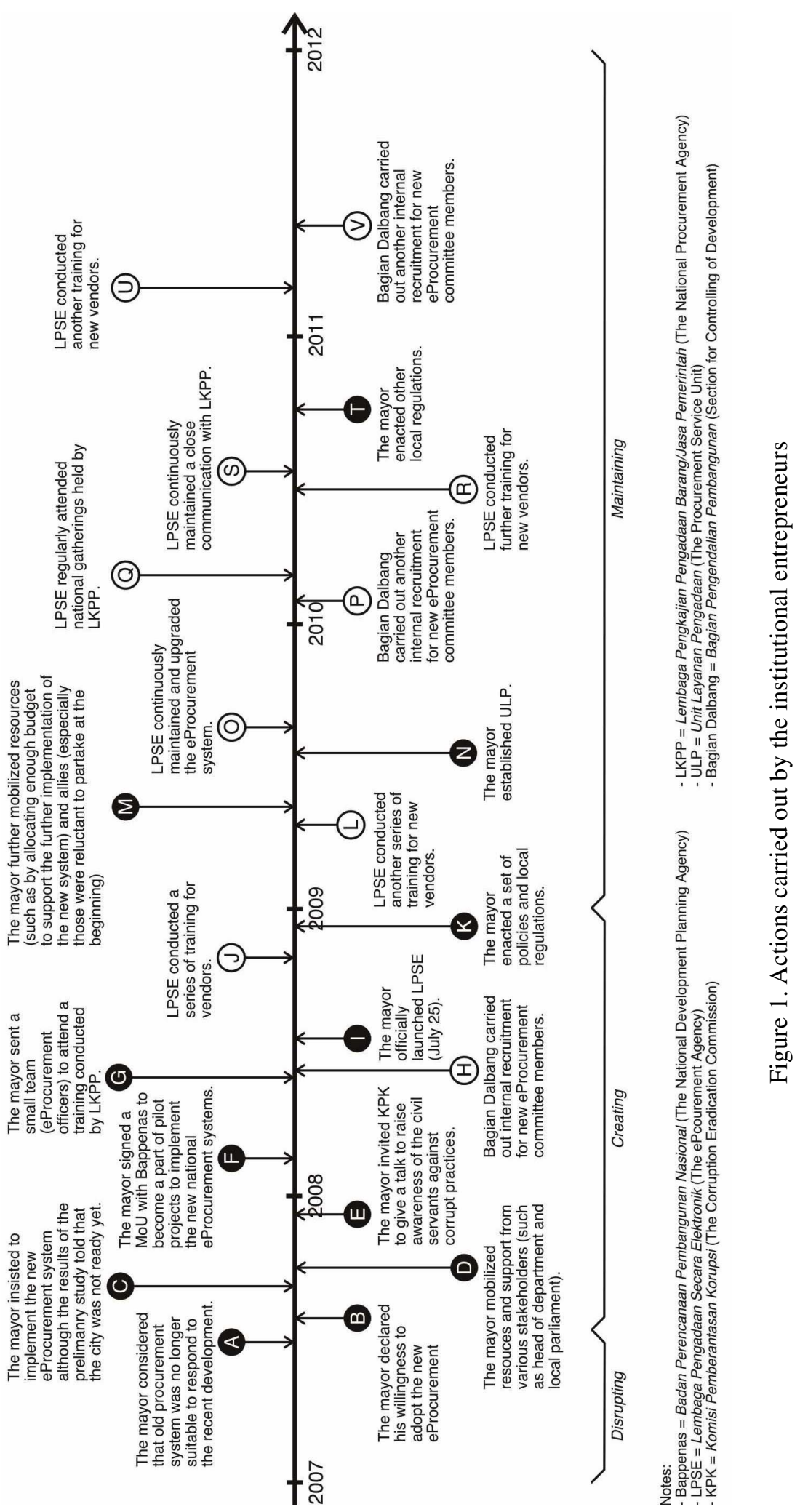


institution. This was done partly to get legitimacy from other actors who could possibly endorse or authorize the new practices [cf. 34]. Policing institutional work aimed at getting endorsement from other local actors to secure legally and legitimately the new practice (point $\mathrm{K}$ ), while connecting to the macro-level discourse (points $\mathrm{F}$ and $\mathrm{G}$ ) and aligning with highly legitimate actors (point E), targeted authorization from the upper authorities. This is important as, to some extent, this kind of institutional work will orchestrate policies at difference levels, which is considered critical in the adoption of the eProcurement systems in the public sector [19].

The mayor adopted deterring, a stronger political institutional work only after the benefits of the new practices had been demonstrated. He did so by exercising coercive power (points $\mathrm{M}$ and $\mathrm{T}$ ) [cf. 6]. This is very important for maintaining the new institution, especially in the context of a highly volatile government where decisions made by one incumbent may be overturned by his successors [5]. The mayor's comment reflects this:

"Visionary orientation of every mayor differs. His/her personality and interest affects his/her political will to a great extent."

The technical institutional work in our case was mainly carried out to maintain the new institution or the practices. The ultimate objective was to stabilize and routinize the new practices and to embed them into the other existing organizational practices [35]. In doing so, the skills and knowledge of the involved actors - the eProcurement officers, the departments, and the vendors - were continuously upgraded through educating institutional work (points $\mathrm{R}$ and $\mathrm{V}$ ). In addition, a set of enabling works was also carried out, such by establishing ULP (point N) and continuously upgrading the Procurement systems and (point O). A certain class of actors (e.g., LPSE, ULP, the department) was assigned to a set of specific tasks related to the various stages in the eProcurement process (point $\mathrm{N}$ ). Here, actors and actions became typified [24] and thereby the new practices became institutionalized.

\section{Conclusion}

Interesting patterns of findings emerged from our study. First, we found that at the beginning of the institutionalization process, for a divergent change, cultural institutional work was very important. This was mainly to create a collective awareness and to develop a new shared identity. However, this is not to say that the cultural institutional work was not needed in subsequent processes, but likely it was less important.

Although political institutional work was identified in the creating and maintaining stages, it seemed that it was exercised differently. In the former stage, it was aimed at facilitating a smooth start to the action, by minimizing the resistance to get the broadest possible support from the involved stakeholders. In the latter stage, it was mainly to make other stakeholders enrol in the practices and simultaneously to deter others. Hence, though it was important, the political coercive power needed to be exercised carefully, by taking into account the emergent development during the process. Technical institutional work was very important mainly in the process of maintaining the new institution. This is an iterative work, and by being so, it was expected that the new practices would become routinized and embedded in the organizational practices.

Perhaps the most intriguing finding was that the involvement of the dominant actor gradually diminished at the later stages of the institutionalized process. Figure 1 shows the frequency of shaded circles diminished at the later stages where clear circles became more frequent. This is a strong indication that the practice has become routinized and institutionalized [10]. The role of institutional actors appears to be to make themselves gradually less conspicuous.

\subsection{Contributions}

Our study offers three main contributions. First, it illustrates that the notion of institutional work provides a better insight into what the institutional entrepreneurs do in the institutionalization process. To the best of our knowledge, no previous study has applied this notion to the context of eGovernment studies. We specifically built upon previous studies by Lawrence and Suddaby [14], Tracey et al. [15], and Dorado [16] to develop a sharper interpretive lens.

Second, the study identifies a set of specific institutional work carried out by the institutional entrepreneurs in the institutionalization process. We traced back the role played by them during the institutionalization stages and revealed in details their institutional work. In general, these institutional works can be grouped into three types: cultural, political and technical, along with the process of disrupting an old institution, and creating and maintaining the new institution.

Third, for practice, our study identifies a set of institutional work for each institutionalization stage. This set can be adopted in other similar contexts, for example to provide insights about possible strategies for implementing an initiative and to minimize resistance to organizational change. The strategies can be structured around some key ideas such as 'values instilling', 'careful exercise of political power', 
'building collective awareness to overcome collective inaction', 'typification' and 'gradual implementation strategy'.

\subsection{Limitations and future research directions}

As with any empirical study, ours has limitations, which also provide directions for future research. These should be carefully considered when looking at the study as a whole. First and foremost, it inherits all the limitations associated with a single case study, for example lack of generalizability in the sense of statistical sample-to-population inference. However, as an interpretive case study, generalization was attained by extrapolating the empirical findings to theory, either a supporting or a rival one [30]. As such, our study contributes to theory refinement.

Moreover, as a single case study, it cannot capture all the possible alternative trajectories of the eProcurement institutionalization. In many cases, eGovernment system implementation is contextsensitive. Including cases from different contexts may provide a more complete picture. This is an important future research avenue. Equally important is research to identify the circumstances under which a certain implementation trajectory is plausible. This can be done, for example, by conducting a cross-case analysis. As an eProcurement system essentially departs from an idea, another interesting future research avenue is bringing in new lens, such as the notion of idea translation [35] to enrich the cross-case analysis.

While our findings provide valuable insights into the types and forms of institutional work carried out by institutional entrepreneurs, they do not tell us about their intentions. To examine this aspect, we can point to some specific theoretical premises. One such relevant premise is the concept of temporal orientation of agency, namely, strategic (future), sensemaking (present) and routine (past) [16]. This concept relates to the intentionality of the actors in doing institutional work [36].

Another relevant concept is element of agency that consists of projective, practical-evaluative, and iterational ones [37]. Projective element of agency encompasses the imagination of the institutional actors towards possible future trajectories of action defined by actors' hopes, fears and desires [37]. Practicalevaluative element of agency is "the capacity of actors to make practical and normative judgments among alternative possible trajectories of action, in response to the emerging demands, dilemmas, and ambiguities of presently evolving situations" [37]. Iterational element of agency and it is done to give stability and order and help sustain identities, interaction and institutions over time [37]. A multiple case study, preferably a longitudinal one based on this theoretical premise can provide us with richer insights into the role of institutional actors and consequently into the institutionalization process.

Essentially, the phenomenon we investigated comes under the umbrella of information and communication technology for development (ICT4D) studies. Generally, the ethical goal of such studies is to create a better world [38]. Here, a better world could be interpreted in various ways, including the provision of effective services to the public and the promotion of services that are in marginal positions (such as small businesses). More generally, this can include empowering the have-nots to allow them to escape from their economic and intellectual poverty. In summary, as many people as possible should benefit from using ICT. Moreover, the discussion on corruption is particularly germane to the ICT4D area, because corruption is one of the main barriers to development [4]. Taken together, the issues of ICT4D offer further interesting avenues for future research.

\section{References}

[1] Walsham, G., and Sahay, S., "Research on information systems in developing countries: Current landscape and future prospects", Information Technology for Development, 12(1), 2006, pp. 17-24.

[2] Heeks, R., "Information systems and developing countries: Failure, success and local improvisations", The Information Society, 18, 2002, pp. 101-112.

[3] Wahid, F., and Sein, M.K., "Institutional entrepreneurs: The driving force in institutionalization of public systems in developing countries", Transforming Government: People, Process and Policy, 7(1), 2013.

[4] Transparency International, Corruption Perception Index 2011, Transparency International, Berlin, 2011.

[5] Furuholt, B., and Wahid, F., "E-government challenges and the role of political leadership in Indonesia: The case of Sragen", Proceedings of the 41st Hawaii International Conference on System Sciences (HICSS) 2008, 2008.

[6] Kim, S., Kim, H.J., and Lee, H., "An institutional analysis of an e-government system for anti-corruption: The case of OPEN", Government Information Quarterly, 26(1), 2009, pp. 42-50.

[7] Dacin, M.T., Goodstein, J., and Scott, W.R., "Institutional Theory and institutional change: Introduction to the special research forum", Academy of Management Journal, 45(1), 2002, pp. 43-56.

[8] Battilana, J., Leca, B., and Boxenbaum, E., "How actors change institutions: Towards a theory of institutional entrepreneurship", The Academy of Management Annals, 3(1), 2009, pp. 65-107.

[9] Currie, W., "Contextualising the IT artefact: Towards a wider research agenda for IS using institutional theory", Information Technology \& People, 22(1), 2009, pp. 63-77.

[10] Avgerou, C., "IT and organizational change: An institutionalist perspective", Information Technology and People, 13(4), 2000, pp. 234-262.

[11] Suddaby, R., "Challenges for institutional theory", Journal 
of Management Inquiry, 19(1), 2010, pp. 14-20.

[12] Mignerat, M., and Rivard, S., "Positioning the institutional perspective in information systems research", Journal of Information Technology, 24(4), 2009, pp. 369391.

[13] Weerakkody, V., Dwivedi, Y.K., and Irani, Z., "The diffusion and use of institutional theory: A cross-disciplinary longitudinal literature survey", Journal of Information Technology, 24(4), 2009, pp. 354-368.

[14] Lawrence, T.B., and Suddaby, R., "Institutions and institutional work", in (Clegg, S., Hardy, C., Lawrence, T.B., and Nord, W.R., 'eds.'): The SAGE Handbook of Organization Studies, Sage Publications, London, 2006, pp. 215-254.

[15] Tracey, P., Phillips, N., and Jarvis, O., "Bridging institutional entrepreneurship and the creation of new organizational forms: A multilevel model", Organization Science, 22(1), 2011, pp. 60-80.

[16] Dorado, S., "Institutional entrepreneurship, partaking, and convening", Organization Studies, 26(3), 2005, pp. 385414.

[17] Croom, S., and Brandon-Jones, A., "Impact of eprocurement: Experiences from implementation in the UK public sector", Journal of Purchasing \& Supply Management, 13, 2007, pp. 294-303.

[18] Transparency International, Handbook for Curbing Corruption in Public Procurement, Transparency International, Berlin, 2008.

[19] Henriksen, H.Z., and Mahnke, V., "E-procurement adoption in the Danish public sector", Scandinavian Journal of Information Systems, 17(2), 2005, pp. 5-26.

[20] Boyne, G.A., "Public and private management: What's the difference?", Journal of Management Studies, 39(1), 2002, pp. 97-122.

[21] Mougeot, M., and Naegelen, F., "A political economy analysis of preferential public procurement policies", European Journal of Political Economy, 21(2), 2005, pp. 483-501.

[22] Oliver, C., "The antecedents of deinstitutionalization", Organization Studies, 13(4), 1992, pp. 563-588.

[23] Perkmann, M., and Spicer, A., "How are management fashions institutionalized? The role of institutional work", Human Relations, 61(6), 2008, pp. 811-844.

[24] Scott, W.R., Institutions and Organizations: Ideas and Interest, Sage, Thousand Oaks, CA, 2008.

[25] Haswidi, A., "E-tendering will improve transparency, official says", The Jakarto Post, 6 January 2007.

[26] The Jakarta Post, "Corruption ingrained in procurement processes", The Jakarta Post, 5 February 2009.

[27] Jones, D.S., "Public procurement in Southeast Asia: Challenge and reform", Journal of Public Procurement, 7(1), 2007, pp. 3-33.

[28] Bygstad, B., and Munkvold, B.E., "Exploring the role of informants in interpretive case study research in IS", Journal of Information Technology, 26(1), 2010, pp. 32-45.

[29] Myers, M.D., and Newman, M., "The qualitative interview in IS research: Examining the craft", Information and Organization, 17, 2007, pp. 2-26.

[30] Yin, R.K., Case Study Research: Design and Methods, Sage, California, 2009.

[31] Langley, A., "Strategies for theorizing from process data", Academy of Management Review, 24(4), 1999, pp. 691-710.

[32] Kredibel, "E-procurement inovasi menuju pengadaan bebas korupsi", Kredibel, 1(1), 2011, pp. 12-13.

[33] Benford, R.D., and Snow, D.A., "Framing processes and social movements: An overview and assessment", Annual Review of Sociology, 26(1), 2000, pp. 611-639.

[34] Walker, H.A., "Beyond power and domination: Legitimacy and formal organizations", in (Johnson, C., 'ed.'): Research in the Sociology of Organizations, Elsevier, Oxford, UK, 2004, pp. 239-271.

[35] Czarniawska, B., and Joerges, B., "Travel of ideas", in (Czarniawska, B., and Sevón, G., 'eds.'): Translating Organizational Change, Walter de Gruyter, Berlin, 1996, pp. 13-48.

[36] Lawrence, T., Suddaby, R., and Leca, B., "Institutional work: Refocusing institutional studies of organization", Journal of Management Inquiry, 20(1), 2011, pp. 52-58.

[37] Emirbayer, M., and Mische, A., "What is agency?", American Journal of Sociology, 103(4), 1998, pp. 962-1023.

[38] Walsham, G., "Are we making a better world with ICTs? Reflections on a future agenda for the IS field", Journal of Information Technology, 27(2), 2012, pp. 87-93. 